\title{
Article \\ Eco-Friendly Production of AuNPs and Their Impact on the Oil Oxidative Stability
}

\author{
Flávio S. Michels ${ }^{1,2, *}$, Pablo J. Gonçalves ${ }^{3}$, Valter A. Nascimento ${ }^{4}\left(\right.$ ) , Samuel L. Oliveira ${ }^{1}$, Heberton Wender ${ }^{2}(\mathbb{C}$ \\ and Anderson R. L. Caires $1, *$ (D) \\ 1 Optics and Photonics Group, Institute of Physics, Federal University of Mato Grosso do Sul, \\ Campo Grande 79070-900, Brazil; samuel.oliveira@ufms.br \\ 2 Nano \& Photon Research Group, Laboratory of Nanomaterials and Applied Nanotechnology (LNNA), \\ Institute of Physics, Federal University of Mato Grosso do Sul, Campo Grande 79070-900, Brazil; \\ heberton.wender@ufms.br \\ 3 Instituto de Física, Universidade Federal de Goiás, Goiânia 74690-900, Brazil; pablo@ufg.br \\ 4 Laboratory of Spectroscopy and Bioinformatics Applied to Biodiversity and Health, Faculty of Medicine, \\ Federal University of Mato Grosso do Sul, Campo Grande 79070-900, Brazil; valter.aragao@ufms.br \\ * Correspondence: flavio.michels@ufms.br (F.S.M.); anderson.caires@ufms.br (A.R.L.C.)
}

check for updates

Citation: Michels, F.S.; Gonçalves, P.J.; Nascimento, V.A.; Oliveira, S.L.; Wender, H.; Caires, A.R.L.

Eco-Friendly Production of AuNPs and Their Impact on the Oil Oxidative Stability. Nanomaterials 2021, 11, 1668. https://doi.org/ 10.3390/nano11071668

Academic Editors: Sónia Carabineiro and Abdelhamid Elaissari

Received: 23 April 2021

Accepted: 15 June 2021

Published: 25 June 2021

Publisher's Note: MDPI stays neutral with regard to jurisdictional claims in published maps and institutional affiliations.

Copyright: (c) 2021 by the authors. Licensee MDPI, Basel, Switzerland. This article is an open access article distributed under the terms and conditions of the Creative Commons Attribution (CC BY) license (https:// creativecommons.org/licenses/by/ $4.0 /)$.

\begin{abstract}
Vegetable oils have been used for different applications and, more recently, as an active host medium to obtain nanoparticles for employment in bionanotechnological applications. Nevertheless, oils are very susceptible to oxidation during production, storage, and transportation because of their chemical composition. Consequently, any modification in their production must be accompanied by an analysis of the oxidative stability. In this study, naked and biocompatible gold nanoparticles (AuNPs) were grown on sunflower oil during sputtering deposition using different deposition times. Size and morphology were determined by transmission electron microscopy (TEM) and their concentrations were found by inductively coupled plasma-optical emission spectroscopy (ICP-OES). Rancimat ${ }^{\circledR}$ method was employed to evaluate the AuNPs influence on the oxidative stability of the vegetable oil. Well-dispersed quasi-spherical NPs were produced with a mean diameter in the 2.9-3.7 $\mathrm{nm}$ range and they were concentration-dependent on the deposition time. A concentration of about $11 \mathrm{mg} / \mathrm{L}, 38 \mathrm{mg} / \mathrm{L}$, and $225 \mathrm{mg} / \mathrm{L}$ of AuNPs was obtained for a deposition time of $5 \mathrm{~min}$, $15 \mathrm{~min}$, and $30 \mathrm{~min}$, respectively. The results also revealed that AuNPs negatively affected the oxidative stability of the sunflower oil and exponentially reduced the induction period (IP) with the increase in AuNPs content. IP reductions of $63 \%, 77 \%$, and $81 \%$ were determined for the AuNPs containing samples at $11 \mathrm{mg} / \mathrm{L}, 38 \mathrm{mg} / \mathrm{L}$, and $225 \mathrm{mg} / \mathrm{L}$. For the first time, it is reported that naked AuNPs promote the rapid degradation of vegetable oil and this points out the need for attention relative to the quality of vegetable oils used to host metal nanoparticles.
\end{abstract}

Keywords: gold nanoparticle; vegetable oil; sunflower; oxidative stability; Rancimat

\section{Introduction}

Engineered nanoparticles have been applied for different purposes, such as intelligent drug delivery [1-5] and cosmetics [6,7]. Nanoparticles (NPs) can be produced by controlling and manipulating matter, breaking larger particles, or regulating the assembly processes [8]. The chemical composition, stability, morphology, and modulation of the NPs' surface strictly impact their physical-chemical characteristics and applications [9-11].

In cosmetics, nanomaterials are promising technological alternatives for the development of innovative cosmetic formulations [12]. NPs have been widely used in sunscreens, deodorants, makeup, anti-aging care, hair, and oral products [13-16]. Nanoformulations containing gold nanoparticles (AuNPs) associated with vegetable oils have received much attention because they can enhance permeation through the outermost layer of the skin, 
which enables, for instance, a transdermal delivery of AuNPs [17]. The permeation efficiency of nanoformulations can be modulated by NPs' characteristics, such as shape, charge, and functionalization $[18,19]$.

Different technological approaches have been developed to synthesize stable nanosystems and, among them, methods using vegetable oils have stood out. Vegetable oils have been used to design multifunctional nanostructured carriers with multiple health benefits [20-23]. These oils possess several advantages over synthetic compounds because of their constituents, such as triglycerides, fatty acids, phenolics, and carotenoids. They present antioxidant, anti-inflammatory, and antimicrobial activities and further protects the skin against reactive oxygen species and synergistically improving, e.g., the photoprotective properties of sunscreens [24-26]. Moreover, the synthesis of NPs using vegetable oils is considered an environmentally friendly chemical approach [27].

Nowadays, the search for eco-friendly routes has received considerable attention and sputtering has proven to be a clean and valuable method to obtain stable, biocompatible, and naked metal NPs in vegetable oils [28]. Sputtering is a physical method able to produce metallic nanoparticles directly in low vapor pressure liquids [10,11,27,29-31]. In this technique, atoms and clusters of atoms may be ejected from the sputtered target in a controlled atmosphere and directly deposited onto the liquid without using chemical stabilizers or toxic reagents, which avoids waste generation; therefore, this method results in a clean, one-step, and simple synthesis process [11,32]. From the physical and chemical point of view, the nucleation and growth of NPs onto liquids by sputtering is governed by different parameters, such as liquid/gas surface chemical composition, liquid substrate coordination ability, discharge voltage, working pressure, liquid substrate temperature, and, among others, sputtered atoms' kinetic energy. For a detailed discussion, readers are referred to a recently published review article [11]. In summary, both the chemistry of the liquid substrate and the physical parameters of the sputtering process itself may be used to tune the final size of the naked colloidal NPs produced. In the case of using synthetic or vegetable oils for producing biocompatible metal NPs through sputtering deposition, Wender et al. (2011) reported for the first time that the underlining mechanism for controlling the formation of thin films or nanoparticles was by simply controlling the oil surface coordination ability and the sputtering discharge voltage [28] where thin films (nanoparticles) were predominant for low (high) coordinating oils and low (high) discharge voltages. In fact, the discharge voltage directly correlates with the atom diffusion rate at the oil surface and, when it is relatively low, the dominant parameter for nanoparticle formation is the surface coordination ability of the oils. That is why thin films are sometimes produced instead of colloidal nanoparticles [33,34]. Therefore, for the obtention of biocompatible $\mathrm{NPs}$, it is highly recommended to use oils with a satisfactory coordination ability (presence of functional groups and/or unsaturated aliphatic chains). In addition, for high diffusion rates (high discharge voltages), a balance between the physical and the chemical parameters needs to be considered when understanding the NPs formation processes.

The biocompatibility of AuNPs has been extensively studied in human cells [35], which is very important for biomedical and cosmetic applications. However, there is an increasing concern regarding their potential cytotoxicity, which depends on the shape, size, concentration, capping agent, host medium, and biological substrate (human cells, cancer cells, bacteria, etc.) [36,37]. Consequently, attention must be paid to these parameters and their relation to the production of biocompatible nanoparticles.

The oxidative stability is an important quality parameter of vegetable oils, which is straightly connected to, e.g., the shelf life. Moreover, storage conditions related to illumination, temperature, humidity, and contaminants can accelerate oxidation [38,39]. Although AuNPs have been proposed to prolong oil preservation, studies have shown that metals in vegetable oils speed up oxidative processes [40-43]. Nevertheless, the effects of metallic NPs on the oxidative stability of vegetable oils have not been investigated yet. The present work reports an eco-friendly route to produce, for the first time, naked and 
biocompatible AuNPs by sputtering deposition onto sunflower oil and investigates the impact of AuNPs on the oxidative stability of sunflower oil.

\section{Materials and Methods}

\subsection{Vegetable Oil}

Sunflower oil $\left(\operatorname{Liza}^{\circledR}\right)$ was used as a medium to produce AuNPs. The sunflower oil was chosen because it oxidizes in a relatively short time scale and this renders it an excellent vegetable oil model for accelerated degradation studies [44].

\subsection{Production of AuNPs}

The AuNPs deposition was performed using a sputtering chamber (Desk III, Denton Vacuum LLC, Moorestown, NJ, USA) with a gold target. The amount of $2 \mathrm{~mL}$ of sunflower oil was added to a glass dish of $5 \mathrm{~cm}$ diameter and placed $12 \mathrm{~cm}$ from the target surface. The chamber was evacuated to around 160 mTorr, followed by argon addition to the chamber up to a working pressure of $330 \mathrm{mTorr}$. Then, the AuNPs were produced applying a current of $41 \mathrm{~mA}$ for three fixed deposition times $(5,15$, and $30 \mathrm{~min})$.

\subsection{Characterization of AuNPs by TEM and EDS}

The formation of AuNPs was investigated using a $200 \mathrm{kV}$ Tecnai G2 (FEI, Eindhoven, The Netherlands) transmission electron microscope (TEM) and energy dispersive spectroscopy (EDS). The samples were prepared by sonicating the colloidal solution under ultrasound for $10 \mathrm{~min}$ and then a thin layer of the liquid containing the NPs using a $3 \mathrm{~mm}$ diameter $\mathrm{Cu}$ hoop dipped in the sample was collected. This thin layer was screened on the surface of a holey carbon copper grid. After drying for $24 \mathrm{~h}$, the grids were analyzed in the microscope. The mean size of the NPs was determined by measuring 500 particles found in the grid, which were assumed to be spherical.

\subsection{Quantification of AuNPs by ICP-OES}

Inductively coupled plasma optical emission spectroscopy (ICP-OES) quantified the AuNPs concentration deposited in the sunflower oil samples. An ICP-OES iCAP 6300 Duo (Thermo Fisher Scientific, Bremen, Germany), with the axial and radial view, and a simultaneous detector CID (Charge Injection Device were used to check the procedure's accuracy. Commercial purity argon 99.999\% (White Martins-Praxair, Campo Grande, Brazil) was used to purge the optics, plasma generation, nebulizer, and auxiliary gas. All determinations from ICP OES were carried out in plasma axial view under the following operating conditions: $1350 \mathrm{~W}$ RF power, $12 \mathrm{~L} / \mathrm{min}$ plasma gas flow rate, $0.75 \mathrm{~L} / \mathrm{m}$ nebulizer gas flow, $50 \mathrm{rpm}$ analysis pump rate, and $30 \mathrm{~s}$ integration times. The Au emission line at $242.795 \mathrm{~nm}$ was monitored.

All working solutions were prepared using ultrapure water $\left(18 \mathrm{M} \mathrm{U} \mathrm{cm}\right.$, Milli- ${ }^{\circledR}$, Millipore, Bedford, MA, USA) and nitric acid (65\%, Merck, Darmstadt, Germany) and hydrogen peroxide (35\%, Merck, Darmstadt, Germany). Single-element stock solutions containing $1000 \mathrm{mg} / \mathrm{L}$ of Au (SpecSol, São Paulo, Brazil) were used to prepare standard reference solutions and to carry out spike experiments.

The samples $(0.5 \mathrm{~mL})$ were weighed in a PTFE digestion vessel. Concentrated $\mathrm{HNO}_{3}$ ( $2 \mathrm{~mL})$ and $\mathrm{H}_{2} \mathrm{O}_{2}(1 \mathrm{~mL})$ were added to the vessel. The decomposition of the samples was carried out in a microwave digestion system SpeedWave (Berghof, Königsee, Germany). The samples were submitted to the step heating procedure exhibited in Table 1. After digestion, the volume was adjusted to $20 \mathrm{~mL}$ to perform the quantification. 
Table 1. Heating program used in the microwave digestion of the samples.

\begin{tabular}{cccc}
\hline Step & Temperature $\left({ }^{\circ} \mathbf{C}\right)$ & Time $($ Min) & Pressure (Bar) \\
\hline 1 & 120 & 10 & 30 \\
2 & 180 & 15 & 30 \\
3 & 250 & 10 & 30 \\
4 & 50 & 10 & 20 \\
\hline
\end{tabular}

For quantitative analysis, calibration curves were built using different concentrations of standard $\mathrm{Au}(0.001,0.0026,0.005,0.01,0.025,0.05,0.1,0.25,0.5,1.0,2.0$, and $4.0 \mathrm{mg} / \mathrm{L})$. The limit of detection (LOD) and quantification (LOQ) were calculated according to IUPAC recommendations in terms of the standard deviation of the baseline $(\mathrm{Sbl}, n=20)$. The LOD $(=3 * \mathrm{Sbl} / \mathrm{m})$ achieved was $0.0006 \mathrm{mg} / \mathrm{L}$, while the $\mathrm{LOQ}(=10 * \mathrm{Sbl} / \mathrm{m})$ was $0.002 \mathrm{mg} / \mathrm{L}$, where $\mathrm{m}$ is the slope of the calibration curve.

\subsection{Oxidative Stability}

The oxidative stability of the samples was determined by the Rancimat method using the 893 Professional Biodiesel Rancimat (Metrohm AG, Herisau, Switzerland). Analyses were carried out by heating $3.0 \mathrm{~g}$ of the sample at $110{ }^{\circ} \mathrm{C}$ under an air-flow of $10 \mathrm{~L} / \mathrm{h}$ according to the European standard EN14112 [45]. The induction period (IP) was obtained from the second derivate of the electrical conductivity versus heating time.

\subsection{Fatty Acid Composition Determination}

The fatty acid content was determined by gas chromatography (GC) with a flame ionization detector (FID) $6890 \mathrm{~N}$ (Agilent, Santa Clara, CA, USA) using the following conditions: injector and detector temperature at $225^{\circ} \mathrm{C}$ and $285^{\circ} \mathrm{C}$, respectively. Hydrogen flow of $40 \mathrm{~mL} / \mathrm{min}$, air flow rate of $450 \mathrm{~mL} / \mathrm{min}$, helium flow rate of $40 \mathrm{~mL} / \mathrm{min}$, injection volume of $1.0 \mu \mathrm{L}$, and column (HP-88 $100 \mathrm{~m} \times 0.250 \mathrm{~mm}$ ). The initial oven temperature program was: $160{ }^{\circ} \mathrm{C}$ for $3 \mathrm{~min}$, ramp from 160 to $190{ }^{\circ} \mathrm{C}$ (heating rate of $3{ }^{\circ} \mathrm{C} / \mathrm{min}$ ) and from 190 to $230{ }^{\circ} \mathrm{C}$ (heating rate of $6{ }^{\circ} \mathrm{C} / \mathrm{min}$ ), and then maintained at $230{ }^{\circ} \mathrm{C}$ for $12 \mathrm{~min}$. The identification of the fatty acid peaks was performed by comparing the relative retention time of existing peaks in the sample with the relative retention time of methyl esters mix pattern fatty acids (Supelco FAME C8-C22, 99\% purity). Relative retention time was calculated by contaminating the samples and the standard mix with an internal standard (Methyl undecanoate). The methyl esters content was determined based on peak areas.

\section{Results and Discussions}

Figure 1 shows the TEM images of the naked AuNPs growth directly in sunflower oil by sputtering deposition. Quasi-spherical particles were obtained for all deposition times and so the particle morphology was time-independent (Figure 1a,d,e). The formation of AuNPs was also confirmed by the emergence of the localized surface plasmon resonance (LSPR) absorption band in the green range (Figure S1, Supplementary Material), as expected for spherical AuNPs. Moreover, the AuNPs presented a mean diameter of ( $2.9 \pm 0.5)$, $(3.7 \pm 0.7)$, and $(3.4 \pm 0.7) \mathrm{nm}$ for the deposition time of 5,15 , and $30 \mathrm{~min}$, respectively (Figure $1 \mathrm{~b}, \mathrm{c}, \mathrm{f})$. These findings revealed that the mean diameters and standard derivation (sigma) were independent of the deposition time. The representative EDS spectrum of the $5 \mathrm{~min}$ sample shows the $\mathrm{M} \alpha, \mathrm{L} \alpha, \mathrm{L} \beta$, and $\mathrm{L} \gamma$ emission lines of the $\mathrm{Au}$, which confirms the chemical composition of the AuNPs (Figure 1g). It is also possible to visualize the $\mathrm{Cu}$ and $\mathrm{Si}$ lines, where the $\mathrm{Cu}$ signal arises from the microscopy grid and the $\mathrm{Si}$ from the oil storage glass. 

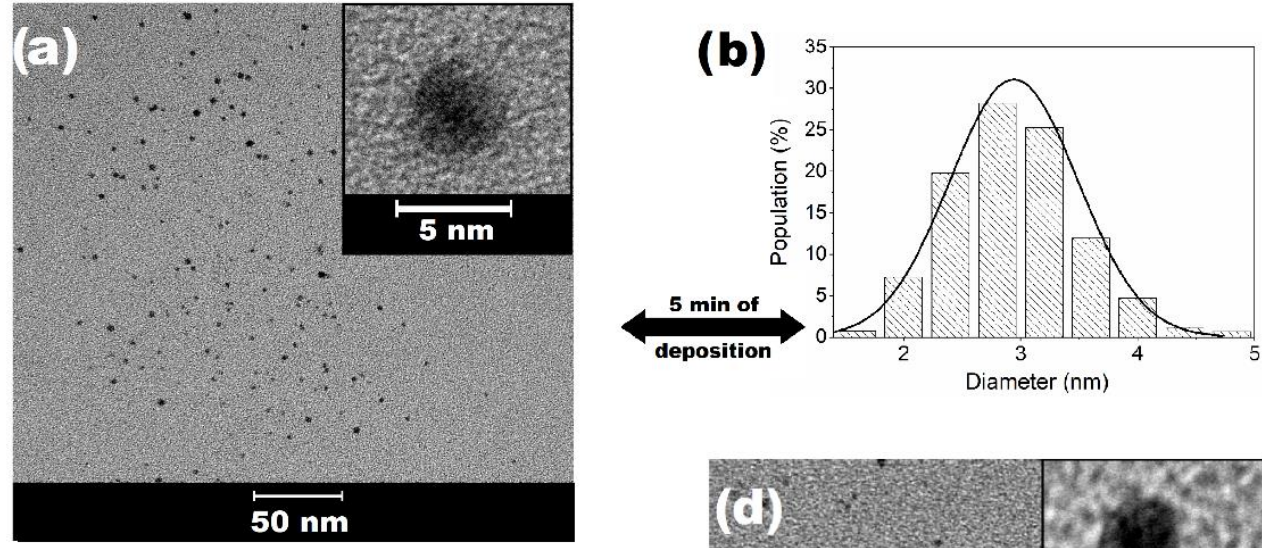

(c)
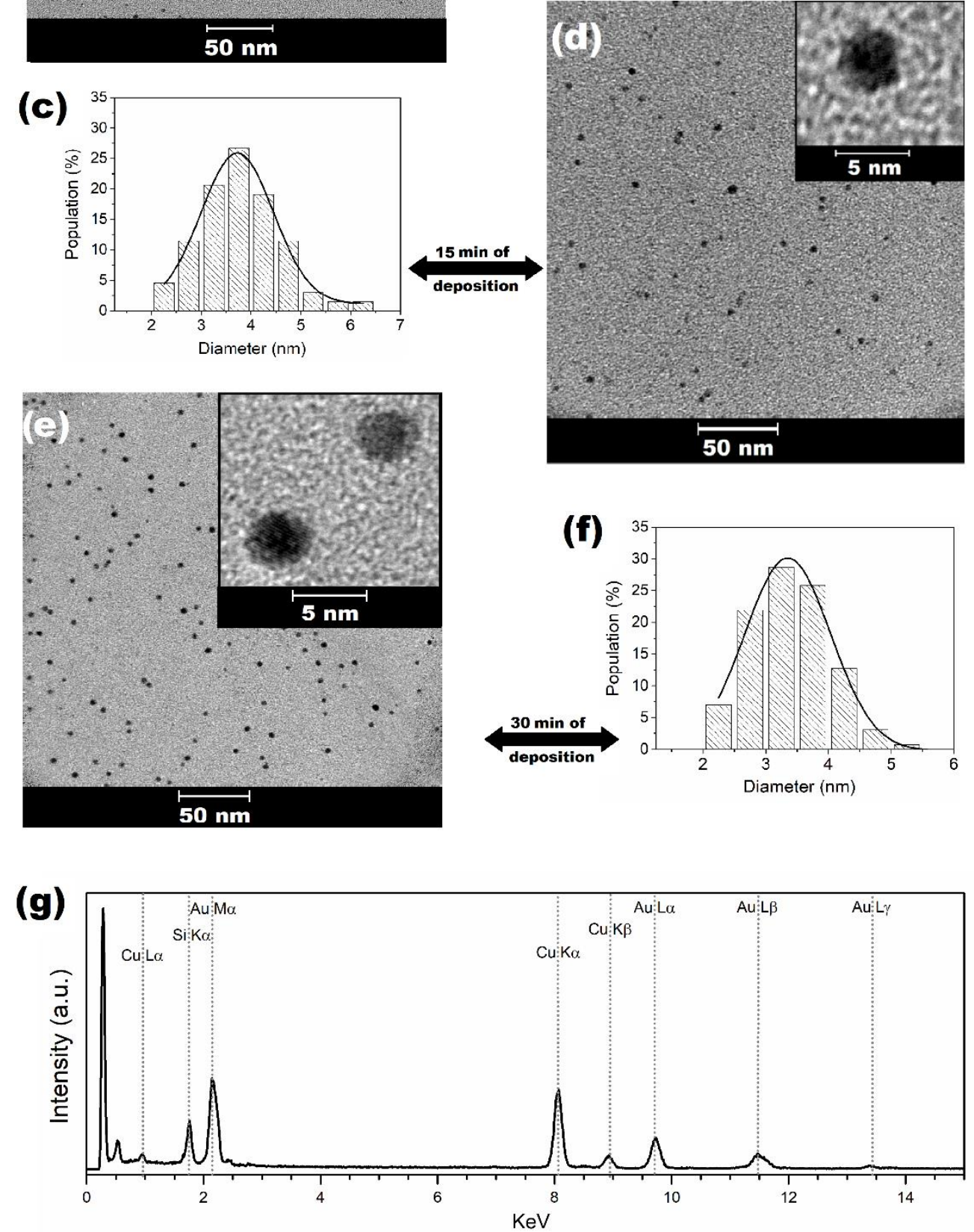

Figure 1. TEM images of AuNPs in the sunflower oil subjected to (a) $5 \mathrm{~min}$, (d) $15 \mathrm{~min}$, and (e) $30 \mathrm{~min}$ of $\mathrm{Au}$ deposition time and their respective histograms of diameter distribution (b,c,f). Representative EDS spectrum (g) of the formed AuNPs in the sunflower vegetable oil during $5.0 \mathrm{~min}$ of Au deposition. 
ICP-OES was used to investigate and quantify the AuNPs concentration deposited in the sunflower oil samples for the different sputtering deposition times, Table 2. As expected, a concentration increase was determined as a function of the deposition time. The higher the deposition time, the higher the concentration of $\mathrm{Au}$ in the obtained colloidal samples. It is also notable that the Au concentration does not follow a linear trend with the sputtering deposition time. This is likely a result of the heating effects in the target in high deposition times, which requires further investigation.

Table 2. Au concentration in sunflower oil for different deposition times and respective accuracy (RSD).

\begin{tabular}{ccc}
\hline Deposition Time (Min) & Concentration $(\mathbf{m g} / \mathrm{L})$ & \%RSD \\
\hline 5.0 & $10.52 \pm 0.09$ & 0.87 \\
15.0 & $38.07 \pm 0.14$ & 0.37 \\
30.0 & $224.58 \pm 10.06$ & 4.54 \\
\hline
\end{tabular}

It is noteworthy to mention that the surface coordination ability of the liquid substrate, viscosity, and the diffusivity of the incoming atoms at the liquid surface are reported among the most important parameters for describing nucleation and the growth of nanoparticles by sputtering deposition on liquids [28,32]. In some cases, thin films may be produced instead of nanoparticles [28]. As all depositions were performed with the same sputtering experimental settings (applied voltage and current at the target) and liquid substrate (sunflower oil), different nanoparticle sizes were not expected. To further obtain insights on the AuNPs formation mechanism by sputtering onto the sunflower oil, the fatty acid composition of the oil was studied, Table 3. As a result, the composition of the sunflower oil is mainly dominated by long unsaturated chain fatty acids, namely, the linoleic and oleic acids, which is as expected [46]. The linoleic fatty acid contains 18 carbons and 2 unsaturations in its chain. Meanwhile, the oleic acid also has a long chain of 18 carbons but with 1 unsaturation. Both acids possess $\mathrm{COOH}$ functional groups and unsaturations that may coordinate the incoming Au atoms and/or clusters-by direct chemical bonding or steric effects, respectively_at the liquid/gas interface during the sputtering deposition, which decreases the diffusivity of the metallic atoms on the oil surface and controlling the NPs nucleation process $[27,28]$. Once the formed nuclei obtain sufficient size to break the liquid surface tension, it is expected that the NPs growth process will occur at the liquid oil phase [27]. This hypothesis is strengthened by the fact that the agglomeration of particles was not observed by TEM, which is expected if the growth occurs at the surface of the liquid, as in the case of silicone oil [47] and caprylic/capric base triglyceride oil [28]. In this last step, the long-chain containing fatty acids protect the individual AuNPs of coalescence by the well-known steric stabilization effect [48-50], which finally explains the small size distribution and excellent dispersity of the samples without the formation of the agglomerated regions. These results are evidence for the high potential for biomedical applications, in general, of this naked and biocompatible AuNPs colloidal solution. However, literature is scarce on the oxidative stability of metal NPs containing oils.

In order to investigate the stability of the sunflower oil as the host medium for the AuNPs, the oxidative stability of the oil was investigated in detail. Figure 2 shows the electrical conductivity values as a function of heating time. A fast rise of the conductivity in the samples containing AuNPs compared to the one without NPs (solid line in Figure 2) can be observed. The difference is highlighted by the induction period (IP) found for the precursor oil and the oil hosts exposed to $5 \mathrm{~min}, 15 \mathrm{~min}$, and $30 \mathrm{~min}$ of deposition time: $(3.14 \pm 0.09),(1.15 \pm 0.04),(0.73 \pm 0.05)$, and $(0.63 \pm 0.06) h$, respectively. Figure 3 shows an exponential decrease in $I P$ as a function of Au concentration, which is described by Equation (1) with $\mathrm{R}^{2}=0.9968$.

$$
I P=0.68+2.46 e^{-[A u N P s] / 6.4} .
$$


These results are evidence that AuNPs negatively impact the oxidative stability of sunflower oil by accelerating its degradation in a dependent manner on the AuNPs concentration.

The accelerated oxidative degradation of the vegetable oil promoted by the AuNPs may be associated with their capacity for producing reactive oxygen species (ROS) [51-56]. It is known that the metal accelerates the oxidation of vegetable oils due to ROS generation $[43,57,58]$. Although there is vast literature on metal and metal-oxide effects on oxidative stability of vegetable oils, the impact of NPs on vegetable oil stability has not been reported yet.

Therefore, these findings highlight the need for studies on the potential impact of NPs on vegetable oils used as a host medium for the design of beneficial products containing multifunctional and biocompatible nanostructured carriers; this is mainly due to the fact that NPs could severely affect the product's shelf life.

Table 3. Fatty acid composition in sunflower oil.

\begin{tabular}{cc}
\hline Fatty Acids & $\%$ \\
\hline Palmitic, C16:0 & $5.9 \pm 0.3^{1}$ \\
Palmitoleic, C16:1 & $0.2 \pm 0.0$ \\
Stearic, C18:0 & $3.2 \pm 0.1$ \\
Oleic, C18:1 & $36.8 \pm 0.3$ \\
Linoleic, C18:2 & $49.5 \pm 0.1$ \\
Linolenic, C18:3 & $0.2 \pm 0.0$ \\
Arachidic, C20:0 & $0.2 \pm 0.0$ \\
Cis-11-Eicosenoic, C20:1 & $0.2 \pm 0.0$ \\
Ducosanoic, C22:0 & $0.6 \pm 0.1$ \\
$\sum$ Saturated & 9.9 \\
$\sum$ Unsaturated & 86.9 \\
\hline
\end{tabular}

${ }^{1}$ The values are means \pm standard derivations.

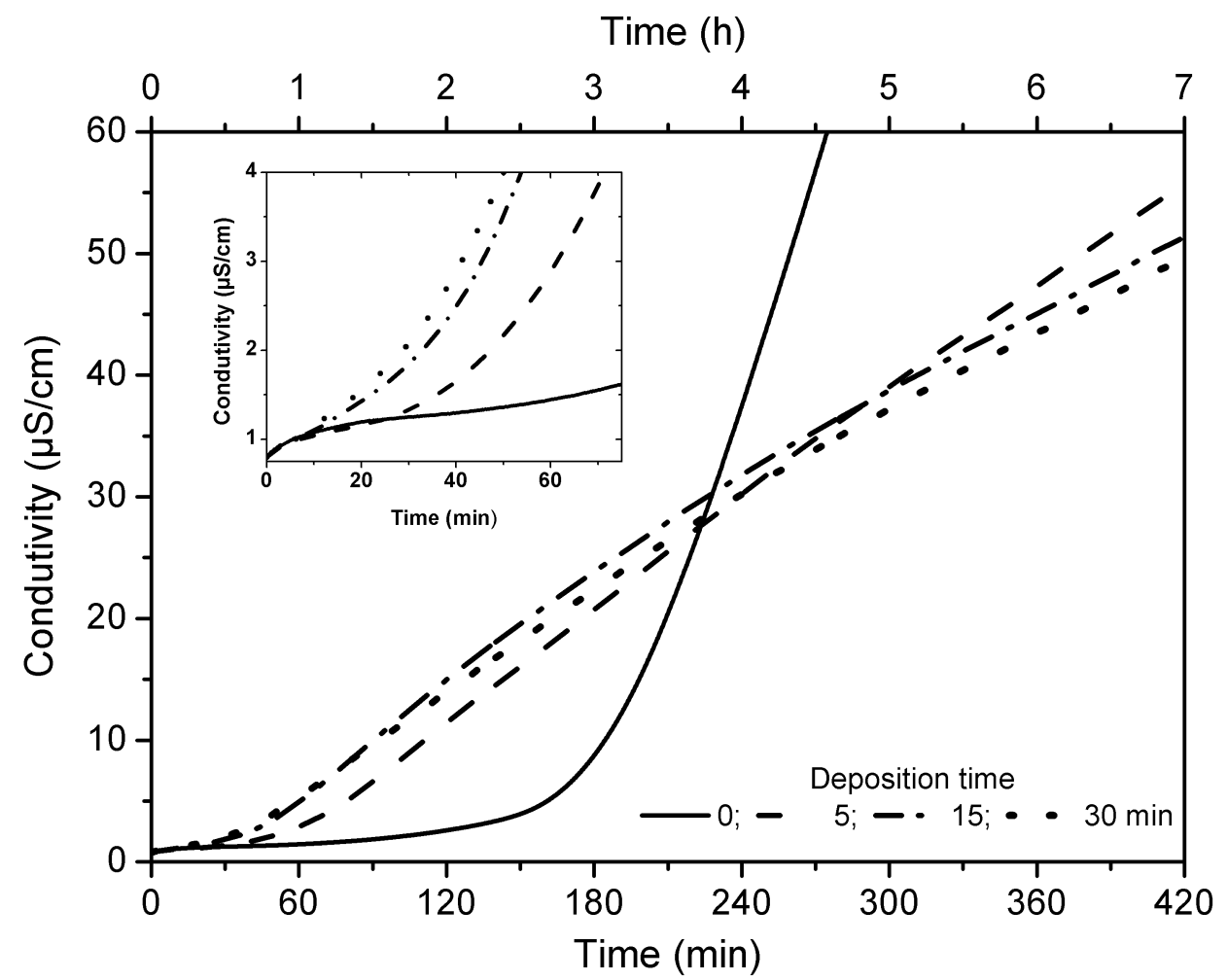

Figure 2. Electrical conductivity as a function of heating time of sunflower oil for different sputtering deposition times. 


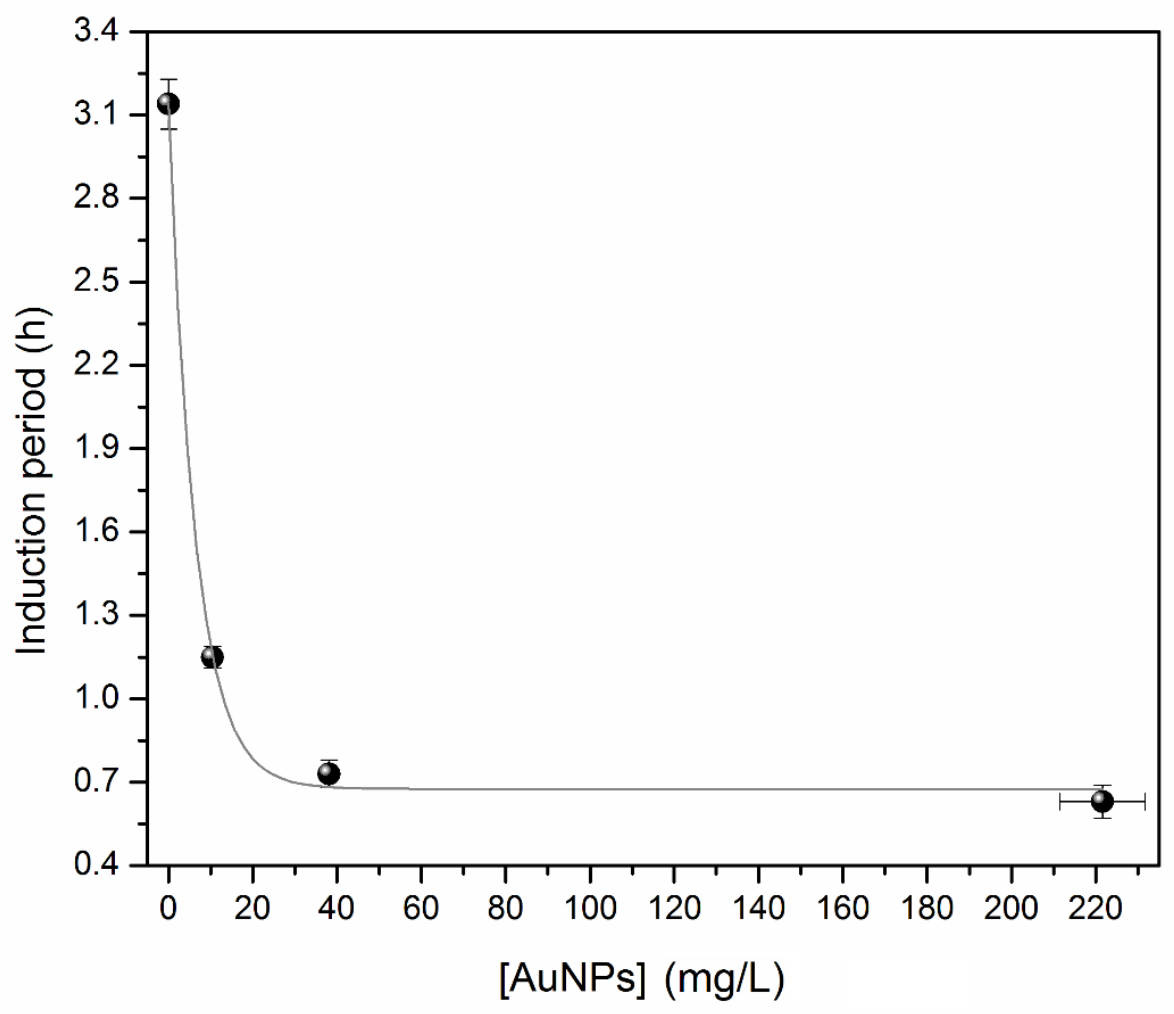

Figure 3. Induction period versus Au content in the vegetable oil.

\section{Conclusions}

Stable naked AuNPs of around $3 \mathrm{~nm}$ diameter were produced using an eco-friendly method based on the use of sunflower vegetable oil and the sputtering technique. Sunflower oil was revealed as an excellent host medium for obtaining small AuNPs $(<5 \mathrm{~nm})$ because of its $\mathrm{COOH}$ functional groups and its long and unsaturated alkyl fatty acid chains. The results also indicate that AuNPs negatively affected the oxidative stability of the sunflower oil and accelerates its oxidation. The IP significantly decreased, presenting a reduction of $63 \%, 77 \%$, and $81 \%$ for AuNPs content of $11 \mathrm{mg} / \mathrm{L}, 38 \mathrm{mg} / \mathrm{L}$, and $225 \mathrm{mg} / \mathrm{L}$. Consequently, AuNPs promote an accelerated oxidative degradation of the vegetal oil and so precautions must be taken to assure the quality control of vegetable oils used to host AuNPs in bionanotechnological products.

Supplementary Materials: The following are available online at https: / www.mdpi.com/article / 10.3390/nano11071668/s1, Figure S1: UV-vis absorption spectra of sunflower oil as function of Au deposition time. INSET. Absorbance at $531 \mathrm{~nm}$, related to the plasmon resonance of AuNPs, as function of the deposition time.

Author Contributions: F.S.M.: investigation, methodology, and writing-original draft. P.J.G.: investigation, formal analysis, and writing-original draft. V.A.N.: methodology and formal analysis. S.L.O.: formal analysis, resources, and writing-review and editing. H.W.: conceptualization, formal analysis, resources, supervision, and writing-review and editing. A.R.L.C.: conceptualization, funding acquisition, project administration, supervision, and writing-review and editing. All authors have read and agreed to the published version of the manuscript.

Funding: This research was funded by Brazilian funding agencies CNPq (grant number: 428932/20185) and FUNDECT. The authors also acknowledge the financial support provided by the CAPES-PrInt funding program (grant numbers: 88887.353061/2019-00, 88881.311921/2018-01 and 88887.311920/ 2018-00) and the National Institute of Science and Technology of Basic Optics and Optics Applied to Life Science (grant number: 465360/2014-9). This study was supported by the Universidade Federal de Mato Grosso do Sul-UFMS/MEC_-Brasil and financed in part by the Coordenação de Aperfeiçoamento de Pessoal de Nível Superior_Brasil (CAPES)—Finance Code 001. 
Data Availability Statement: Data are available upon request from the authors.

Acknowledgments: The authors are grateful to the Brazilian funding agencies CNPq, CAPES, and FUNDECT. This study was supported by the Universidade Federal de Mato Grosso do SulUFMS/MEC - Brasil and financed in part by the Coordenação de Aperfeiçoamento de Pessoal de Nível Superior-Brasil (CAPES)—Finance Code 001.

Conflicts of Interest: The authors declare no conflict of interest.

\section{References}

1. Ghosh, P.; Han, G.; De, M.; Kim, C.; Rotello, V. Gold Nanoparticles in Delivery Applications. Adv. Drug Deliv. Rev. 2008, 60. [CrossRef] [PubMed]

2. Zhang, P.; Liu, X.; Hu, W.; Bai, Y.; Zhang, L. Preparation and Evaluation of Naringenin-Loaded Sulfobutylether- $\beta$ Cyclodextrin/Chitosan Nanoparticles for Ocular Drug Delivery. Carbohydr. Polym. 2016, 149. [CrossRef] [PubMed]

3. El-Kady, A.M.; Farag, M.M.; El-Rashedi, A.M.I. Bioactive Glass Nanoparticles Designed for Multiple Deliveries of Lithium Ions and Drugs: Curative and Restorative Bone Treatment. Eur. J. Pharm. Sci. 2016, 91. [CrossRef]

4. Braun, K.; Pochert, A.; Lindén, M.; Davoudi, M.; Schmidtchen, A.; Nordström, R.; Malmsten, M. Membrane Interactions of Mesoporous Silica Nanoparticles as Carriers of Antimicrobial Peptides. J. Colloid Interface Sci. 2016, 475. [CrossRef] [PubMed]

5. Chitemere, R.P.; Stafslien, S.; Rasulev, B.; Webster, D.C.; Quadir, M. Soysome: A Surfactant-Free, Fully Biobased, Self-Assembled Platform for Nanoscale Drug Delivery Applications. ACS Appl. Bio Mater. 2018, 1. [CrossRef]

6. Suter, F.; Schmid, D.; Wandrey, F.; Zülli, F. Heptapeptide-Loaded Solid Lipid Nanoparticles for Cosmetic Anti-Aging Applications. Eur. J. Pharm. Biopharm. 2016, 108. [CrossRef] [PubMed]

7. Pardeike, J.; Hommoss, A.; Müller, R.H. Lipid Nanoparticles (SLN, NLC) in Cosmetic and Pharmaceutical Dermal Products. Int. J. Pharm. 2009, 366. [CrossRef]

8. Black, C. Health and Safety Issues With Antistatic Agents. In Handbook of Antistatics; Elsevier: Amsterdam, The Netherlands, 2016.

9. Song, H.-T.; Choi, J.; Huh, Y.-M.; Kim, S.; Jun, Y.; Suh, J.-S.; Cheon, J. Surface Modulation of Magnetic Nanocrystals in the Development of Highly Efficient Magnetic Resonance Probes for Intracellular Labeling. J. Am. Chem. Soc. 2005, 127. [CrossRef]

10. Nguyen, M.T.; Yonezawa, T. Sputtering onto a Liquid: Interesting Physical Preparation Method for Multi-Metallic Nanoparticles. Sci. Technol. Adv. Mater. 2018, 19. [CrossRef]

11. Wender, H.; Migowski, P.; Feil, A.F.; Teixeira, S.R.; Dupont, J. Sputtering Deposition of Nanoparticles onto Liquid Substrates: Recent Advances and Future Trends. Coord. Chem. Rev. 2013, 257. [CrossRef]

12. Kaul, S.; Gulati, N.; Verma, D.; Mukherjee, S.; Nagaich, U. Role of Nanotechnology in Cosmeceuticals: A Review of Recent Advances. J. Pharm. 2018, 2018, 1-19. [CrossRef] [PubMed]

13. Khezri, K.; Saeedi, M.; Maleki Dizaj, S. Application of Nanoparticles in Percutaneous Delivery of Active Ingredients in Cosmetic Preparations. Biomed. Pharmacother. 2018, 106. [CrossRef]

14. Frizzo, M.S.; Feuser, P.E.; Berres, P.H.; Ricci-Júnior, E.; Campos, C.E.M.; Costa, C.; de Araújo, P.H.H.; Sayer, C. Simultaneous Encapsulation of Zinc Oxide and Octocrylene in Poly (Methyl Methacrylate-Co-Styrene) Nanoparticles Obtained by Miniemulsion Polymerization for Use in Sunscreen Formulations. Colloids Surf. A Physicochem. Eng. Asp. 2019, 561. [CrossRef]

15. Gubitosa, J.; Rizzi, V.; Lopedota, A.; Fini, P.; Laurenzana, A.; Fibbi, G.; Fanelli, F.; Petrella, A.; Laquintana, V.; Denora, N.; et al. One Pot Environmental Friendly Synthesis of Gold Nanoparticles Using Punica Granatum Juice: A Novel Antioxidant Agent for Future Dermatological and Cosmetic Applications. J. Colloid Interface Sci. 2018, 521. [CrossRef]

16. Ballarin, B.; Mignani, A.; Mogavero, F.; Gabbanini, S.; Morigi, M. Hybrid Material Based on ZnAl Hydrotalcite and Silver Nanoparticles for Deodorant Formulation. Appl. Clay Sci. 2015, 114. [CrossRef]

17. Dhal, S.; Pal, K.; Giri, S. Transdermal Delivery of Gold Nanoparticles by a Soybean Oil-Based Oleogel under Iontophoresis. ACS Appl. Bio Mater. 2020, 3. [CrossRef]

18. Gupta, R.; Rai, B. Effect of Size and Surface Charge of Gold Nanoparticles on Their Skin Permeability: A Molecular Dynamics Study. Sci. Rep. 2017, 7. [CrossRef]

19. Omrani, E.; Siddaiah, A.; Moghadam, A.D.; Garg, U.; Rohatgi, P.; Menezes, P.L. Ball Milled Graphene Nano Additives for Enhancing Sliding Contact in Vegetable Oil. Nanomaterials 2021, 11. [CrossRef]

20. Pinto, F.; de Barros, D.P.C.; Fonseca, L.P. Design of Multifunctional Nanostructured Lipid Carriers Enriched with $\alpha$-Tocopherol Using Vegetable Oils. Ind. Crop. Prod. 2018, 118. [CrossRef]

21. Lacatusu, I.; Niculae, G.; Badea, N.; Stan, R.; Popa, O.; Oprea, O.; Meghea, A. Design of Soft Lipid Nanocarriers Based on Bioactive Vegetable Oils with Multiple Health Benefits. Chem. Eng. J. 2014, 246. [CrossRef]

22. Park, H.; Yang, S.; Kang, J.Y.; Park, M.-H. On-Demand Drug Delivery System Using Micro-Organogels with Gold Nanorods. ACS Med. Chem. Lett. 2016, 7. [CrossRef]

23. Vergallo, C. Nutraceutical Vegetable Oil Nanoformulations for Prevention and Management of Diseases. Nanomaterials 2020, 10, 1232. [CrossRef]

24. Dario, M.F.; Oliveira, F.F.; Marins, D.S.S.; Baby, A.R.; Velasco, M.V.R.; Löbenberg, R.; Bou-Chacra, N.A. Synergistic Photoprotective Activity of Nanocarrier Containing Oil of Acrocomia Aculeata (Jacq.) Lodd. Ex. Martius-Arecaceae. Ind. Crops Prod. 2018, 112. [CrossRef] 
25. Tehranifar, A.; Selahvarzi, Y.; Kharrazi, M.; Bakhsh, V.J. High Potential of Agro-Industrial by-Products of Pomegranate (Punica Granatum L.) as the Powerful Antifungal and Antioxidant Substances. Ind. Crop. Prod. 2011, 34. [CrossRef]

26. Dhavamani, S.; Poorna Chandra Rao, Y.; Lokesh, B.R. Total Antioxidant Activity of Selected Vegetable Oils and Their Influence on Total Antioxidant Values in Vivo: A Photochemiluminescence Based Analysis. Food Chem. 2014, 164. [CrossRef] [PubMed]

27. Wender, H.; de Oliveira, L.F.; Feil, A.F.; Lissner, E.; Migowski, P.; Meneghetti, M.R.; Teixeira, S.R.; Dupont, J. Synthesis of Gold Nanoparticles in a Biocompatible Fluid from Sputtering Deposition onto Castor Oil. Chem. Commun. 2010, 46. [CrossRef] [PubMed]

28. Wender, H.; Gonçalves, R.V.; Feil, A.F.; Migowski, P.; Poletto, F.S.; Pohlmann, A.R.; Dupont, J.; Teixeira, S.R. Sputtering onto Liquids: From Thin Films to Nanoparticles. J. Phys. Chem. C 2011, 115. [CrossRef]

29. Wender, H.; de Oliveira, L.F.; Migowski, P.; Feil, A.F.; Lissner, E.; Prechtl, M.H.G.; Teixeira, S.R.; Dupont, J. Ionic Liquid Surface Composition Controls the Size of Gold Nanoparticles Prepared by Sputtering Deposition. J. Phys. Chem. C 2010, 114. [CrossRef]

30. Wender, H.; Migowski, P.; Feil, A.F.; de Oliveira, L.F.; Prechtl, M.H.G.; Leal, R.; Machado, G.; Teixeira, S.R.; Dupont, J. On the Formation of Anisotropic Gold Nanoparticles by Sputtering onto a Nitrile Functionalised Ionic Liquid. Phys. Chem. Chem. Phys. 2011, 13. [CrossRef]

31. Castro, H.P.S.; Wender, H.; Alencar, M.A.R.C.; Teixeira, S.R.; Dupont, J.; Hickmann, J.M. Third-Order Nonlinear Optical Response of Colloidal Gold Nanoparticles Prepared by Sputtering Deposition. J. Appl. Phys. 2013, 114. [CrossRef]

32. Ishida, Y.; Nakabayashi, R.; Corpuz, R.D.; Yonezawa, T. Water-Dispersible Fluorescent Silver Nanoparticles via Sputtering Deposition over Liquid Polymer Using a Very Short Thiol Ligand. Colloids Surf. A Physicochem. Eng. Asp. 2017, 518. [CrossRef]

33. Venables, J.A.; Spiller, G.D.T.; Hanbucken, M. Nucleation and Growth of Thin Films. Rep. Prog. Phys. 1984, 47. [CrossRef]

34. Yu, S.-J.; Zhang, Y.-J.; Chen, M.-G. Comparision of Stree Relief Mechanisms of Metal Films Deposited on Liquid Substrates by Thermal Evaporating and Sputtering. Int. J. Mod. Phys. B 2010, 24. [CrossRef]

35. Fan, J.H.; Hung, W.I.; Li, W.T.; Yeh, J.M. Biocompatibility Study of Gold Nanoparticles to Human Cells. In Proceedings of the 13th International Conference on Biomedical Engineering, Singapore, 3-6 December 2008; Springer: Berlin/Heidelberg, Gremany, 2009; pp. 870-873.

36. Shukla, R.; Bansal, V.; Chaudhary, M.; Basu, A.; Bhonde, R.R.; Sastry, M. Biocompatibility of Gold Nanoparticles and Their Endocytotic Fate Inside the Cellular Compartment: A Microscopic Overview. Langmuir 2005, 21. [CrossRef] [PubMed]

37. Mieszawska, A.J.; Mulder, W.J.M.; Fayad, Z.A.; Cormode, D.P. Multifunctional Gold Nanoparticles for Diagnosis and Therapy of Disease. Mol. Pharm. 2013, 10. [CrossRef] [PubMed]

38. Li, H.; Fan, Y.; Li, J.; Tang, L.; Hu, J.; Deng, Z. Evaluating and Predicting the Oxidative Stability of Vegetable Oils with Different Fatty Acid Compositions. J. Food Sci. 2013, 78. [CrossRef]

39. Pardauil, J.J.R.; Souza, L.K.C.; Molfetta, F.A.; Zamian, J.R.; Rocha Filho, G.N.; da Costa, C.E.F. Determination of the Oxidative Stability by DSC of Vegetable Oils from the Amazonian Area. Bioresour. Technol. 2011, 102. [CrossRef]

40. Trindade, A.S.N.; Dantas, A.F.; Lima, D.C.; Ferreira, S.L.C.; Teixeira, L.S.G. Multivariate Optimization of Ultrasound-Assisted Extraction for Determination of $\mathrm{Cu}, \mathrm{Fe}, \mathrm{Ni}$ and $\mathrm{Zn}$ in Vegetable Oils by High-Resolution Continuum Source Atomic Absorption Spectrometry. Food Chem. 2015, 185. [CrossRef]

41. Nunes, L.S.; Barbosa, J.T.P.; Fernandes, A.P.; Lemos, V.A.; dos Santos, W.N.L.; Korn, M.G.A.; Teixeira, L.S.G. Multi-Element Determination of $\mathrm{Cu}, \mathrm{Fe}, \mathrm{Ni}$ and $\mathrm{Zn}$ Content in Vegetable Oils Samples by High-Resolution Continuum Source Atomic Absorption Spectrometry and Microemulsion Sample Preparation. Food Chem. 2011, 127. [CrossRef]

42. Zhu, F.; Fan, W.; Wang, X.; Qu, L.; Yao, S. Health Risk Assessment of Eight Heavy Metals in Nine Varieties of Edible Vegetable Oils Consumed in China. Food Chem. Toxicol. 2011, 49. [CrossRef] [PubMed]

43. Choe, E.; Min, D.B. Mechanisms and Factors for Edible Oil Oxidation. Compr. Rev. Food Sci. Food Saf. 2006, 5, 169-186. [CrossRef]

44. Michels, F.S.; Trindade, M.A.G.; Falcão, E.A.; Guimarães, R.C.A.; Oliveira, S.L.; Caires, A.R.L. The Effect of the Excitation Light Intensity during On-Line Monitoring of Biodiesel by Fluorescence Spectroscopy. Fuel 2017, 193. [CrossRef]

45. British Standards Institution. BS EN 14112:2003 Fatty Acid Methyl Esters (FAME)-Determination of Oxidation Stability (Accelerated Oxidation Test). Eur. Comm. Stand 2003, 3, 18.

46. Orsavova, J.; Misurcova, L.; Ambrozova, J.; Vicha, R.; Mlcek, J. Fatty Acids Composition of Vegetable Oils and Its Contribution to Dietary Energy Intake and Dependence of Cardiovascular Mortality on Dietary Intake of Fatty Acids. Int. J. Mol. Sci. 2015, 16, 2871. [CrossRef]

47. Ye, G.; Zhang, Q.; Feng, C.; Ge, H.; Jiao, Z. Structural and Electrical Properties of a Metallic Rough-Thin-Film System Deposited on Liquid Substrates. Phys. Rev. B 1996, 54. [CrossRef]

48. Dupont, J.; Scholten, J.D. On the Structural and Surface Properties of Transition-Metal Nanoparticles in Ionic Liquids. Chem. Soc. Rev. 2010, 39. [CrossRef]

49. Yuan, Q.; Williams, R.A. CO-Stabilisation Mechanisms of Nanoparticles and Surfactants in Pickering Emulsions Produced by Membrane Emulsification. J. Membr. Sci. 2016, 497. [CrossRef]

50. Migowski, P.; Teixeira, S.R.; Machado, G.; Alves, M.C.M.; Geshev, J.; Dupont, J. Structural and Magnetic Characterization of Ni Nanoparticles Synthesized in Ionic Liquids. J. Electron. Spectrosc. Relat. Phenom. 2007, 156-158. [CrossRef]

51. Zhang, W.; Li, Y.; Niu, J.; Chen, Y. Photogeneration of Reactive Oxygen Species on Uncoated Silver, Gold, Nickel, and Silicon Nanoparticles and Their Antibacterial Effects. Langmuir 2013, 29. [CrossRef] 
52. Yu, Z.; Li, Q.; Wang, J.; Yu, Y.; Wang, Y.; Zhou, Q.; Li, P. Reactive Oxygen Species-Related Nanoparticle Toxicity in the Biomedical Field. Nanoscale Res. Lett. 2020, 15. [CrossRef]

53. Martinez-Torres, A.C.; Lorenzo-Anota, H.Y.; García-Juárez, M.G.; Zárate-Triviño, D.G.; Rodriguez-Padilla, C. Chitosan Gold Nanoparticles Induce Different ROS-Dependent Cell Death Modalities in Leukemic Cells. Int. J. Nanomed. 2019, 14. [CrossRef] [PubMed]

54. Piryazev, A.P.; Azizova, O.A.; Aseichev, A.V.; Dudnik, L.B.; Sergienko, V.I. Effect of Gold Nanoparticles on Production of Reactive Oxygen Species by Human Peripheral Blood Leukocytes Stimulated with Opsonized Zymosan. Bull. Exp. Biol. Med. 2013, 156. [CrossRef]

55. Zhao, G.; Wu, X.; Chen, P.; Zhang, L.; Yang, C.S.; Zhang, J. Selenium Nanoparticles Are More Efficient than Sodium Selenite in Producing Reactive Oxygen Species and Hyper-Accumulation of Selenium Nanoparticles in Cancer Cells Generates Potent Therapeutic Effects. Free Radic. Biol. Med. 2018, 126. [CrossRef]

56. Wang, L.; Sun, J.; Lin, L.; Fu, Y.; Alenius, H.; Lindsey, K.; Chen, C. Silver Nanoparticles Regulate Arabidopsis Root Growth by Concentration-Dependent Modification of Reactive Oxygen Species Accumulation and Cell Division. Ecotoxicol. Environ. Saf. 2020, 190. [CrossRef] [PubMed]

57. Mujtaba, M.A.; Muk Cho, H.; Masjuki, H.H.; Kalam, M.A.; Ong, H.C.; Gul, M.; Harith, M.H.; Yusoff, M.N.A.M. Critical Review on Sesame Seed Oil and Its Methyl Ester on Cold Flow and Oxidation Stability. Energy Rep. 2020, 6. [CrossRef]

58. Turek, C.; Stintzing, F.C. Stability of Essential Oils: A Review. Compr. Rev. Food Sci. Food Saf. 2013, 12. [CrossRef] 